\title{
IMPLEMENTASI MANAJEMEN PENDIDIKAN AKHLAK DI MANDRASAH ALIYAH NEGERI (MAN) 1 LOMBOK TIMUR
}

\author{
Muhamad Zaril Gapari \\ STIT Palapa Nusantara \\ zagap205@yahoo.co.id
}

\begin{abstract}
Student moral decline, it takes a serious effort from the school to anticipate various forms of student delinquency in school. One way that can be taken is to build students' morals so that they are noble, responsible, strong, and honest personalities, and form strong characters in their lives, especially morals in the form of morality. Efforts to form good morals in students, systematic arrangements are needed, such as teaching management or the learning process. Through the learning process, schools need to pay attention to the development and improvement of mentality in students. Thus, a special management is needed that is developed by the school to improve students' moral quality. For this reason, integrated steps are needed from various parties, both schools, teachers, students, student organizations, and the participation of parents. Based on the description above, this study intends to find out how the implementation program of moral education in students in the context of moral education management applied by East Lombok State Madrasah Aliyah (MAN) 1 is a preventive / repressive effort in dealing with the usual forms of student / teenage delinquency in school and also included outside of school because the most important is also in overcoming the delinquency process.

This study uses a qualitative approach. The research subjects were principals, teachers, employees, students, parents of students. While the research informants were principals, teachers, school committees, parents, community leaders, students. Data collection techniques using the method of observation, interviews, and documentation. The data validity technique uses an extension of participation, persistence of observation, triangulation (methods and sources). Data analysis techniques using interactive models consist of data collection, data reduction, data presentation and verification. The results showed that 1) Implementation of management of moral education in students of MAN 1 East Lombok: a) carried out through intraculicular, extracurricular and habituation activities. The implementation of management runs in a structured, integrated and normative manner based on Islamic values, as well as by example. b) The principal in MAN 1 East Lombok has carried out management functions namely planning, organizing, coordinating, directing, monitoring and evaluating.
\end{abstract}

Keywords: Management implementation and student moral education. 
Abstrak: Kemerosotan akhlak pelajar, diperlukan sebuah usaha yang sungguhsungguh dari pihak sekolah untuk mengantisipasi berbagai bentuk kenakalan siswa di sekolah. Salah satu cara yang dapat ditempuh adalah membangun akhlak siswa agar berbudi pekerti luhur, bertanggung jawab, berkepribadian kuat, dan jujur, serta membentuk karakter yang kuat dalam kehidupannya terutama moral yang berbentuk akhlakul karimah. Upaya membentuk akhlak yang baik pada diri siswa, diperlukan pengaturan yang sistematis, seperti halnya manajemen pengajaran atau proses pembelajaran. Melalui proses pembelajaran, sekolah perlu memperhatikan pengembangan dan memperbaiki mental pada peserta didik. Dengan demikianlain, diperlukan sebuah manajemen khusus yang dikembangkan pihak sekolah untuk meningkatkan kualitas akhlak siswa. Untuk itu, diperlukan langkah terpadu dari berbagai pihak, baik sekolah, guru, siswa, organisasi kesiswaan, maupun peran serta orang tua siswa. Berdasarkan uraian di atas, penelitian ini bermaksud mengetahui bagaimana program implementasi pendidikan akhlak pada siswa dalam konteks manajemen pendidikan akhlak yang diberlakukan oleh Madrasah Aliyah Negeri (MAN) 1 Lombok Timur sebagai upaya preventif/represif dalam mengatasi bentukbentuk kenakalan siswa/remaja yang biasa terjadi di sekolah dan juga termasuk diluar sekolah karena yang paling penting juga dalam menanggulangi proses kenakalannya. Penelitian ini menggunakan pendekatan kualitatif. Subjek penelitian adalah kepala sekolah, guru, karyawan, siswa, orang tua siswa. Sedangkan informan penelitian adalah kepala sekolah, guru, komite sekolah, orang tua, tokoh masyarakat, siswa. Teknik pengumpulan data menggunakan metode observasi, wawancara, dan dokumentasi. Teknik keabsahan data menggunakan perpanjangan keikutsertaan, ketekunan pengamatan, triangulasi (metode dan sumber). Teknik analisa data menggunakan model interaktif terdiri dari pengumpulan data, reduksi data, penyajian data dan verifikasi. Hasil penelitian menunjukkan bahwa 1) Implementasi manajemen pendidikan akhlak siswa MAN 1 Lombok Timur: a) dilakukan melalui kegiatan intrakulikuler, ekstrakulikuler, dan pembiasaan. Pelaksanaan manajemen tersebut berjalan secara terstruktur, terpadu, dan normatif yang dilandasi oleh nilai-nilai islam, serta dengan keteladanan. b) Kepala sekolah di MAN 1 Lombok Timur telah menjalankan fungsi-fungsi manajemen yaitu perencanaan, pengorganisasian, pengkordinasian, pengarahan, pengawasan dan penilaian.

Kata Kunci: Implementasi manajemen dan pendidikan akhlak siswa.

\section{PENDAHULUAN}

Berkaitan dengan banyaknya kenakalan remaja/siswa yang mengakibatkan dekadensi moral tersebut, sekolah sering dituntut untuk bertanggung jawab terhadap fenomena tersebut. Sekolah sebagai sebuah lembaga pendidikan diharapkan tidak hanya sebagai tempat untuk memperoleh ilmu pengetahuan saja, tetapi juga diharapkan dapat memberi bekal yang cukup dalam membentuk kepribadian siswa yang tangguh dalam menghadapi era globalisasi. Demikian juga ajaran-ajaran moral 
dan tata nilai yang berlaku di masyarakat juga menjadi prioritas yang tidak dapat diabaikan sekolah untuk ditanamkan kepada siswa. Hal ini tercantum dalam UndangUndang Nomor 20 Tahun 2003 tentang Sistem Pendidikan Nasional menyebutkan bahwa "tujuan pendidikan nasional adalah mengembangkan potensi peserta didik agar menjadi manusia yang beriman dan bertakwa kepada Tuhan Yang Maha Esa, berakhlak mulia, sehat, berilmu, cakap dan kreatif, mandiri dan menjadi warga negara yang demokratis serta bertangungjawab". Berkaitan dengan tujuan pendidikan di atas, sekolah mempunyai peranan penting adalah untuk mempersiapkan anak didik agar tidak hanya cerdas atau pandai saja, tetapi juga harus bertakwa, berperilaku baik, bertanggung jawab, dan mempunyai etika yang baik. Sekolah berperan untuk menumbuh kembangkan, membentuk, dan memproduksi pendidikan berwawasan ranah kognitif, afektif, dan psikomotorik. Lembaga pendidikan sebagai pranata sosial yang memberikan jasa layanan bersifat intelektual, afektif, psikomotorik, emosional, dan bahkan spiritual. ${ }^{1}$ Dan juga lembaga pendidikan dapat membentuk karakter yang kuat untuk dapat menanggulangi dekadensi moral dalam kehidupan sehari-hari baik di lingkungan sekolah maupun keluarga dan masyarakat. ${ }^{2}$

Peran penting sekolah di atas adalah upaya menjadikan sekolah yang unggul dengan mengedepankan sisi-sisi moralitas, sebab sekolah yang unggul adalah sekolah yang mampu bersaing dalam hal moral. Sekolah berupaya membentuk dan mengembangkan moral peserta didik. ${ }^{3}$ Sekolah yang unggul adalah yang berfokus pada peningkatan pengetahuan, keterampilan, dan karakter peserta didik. Dengan demikian sekolah diharapkan mampu mengembangkan dimensi spiritual dalam upaya penanggulangan bahaya dekadensi moral siswa-siswi pelajar di tingkat SMK/SMA/MA.

${ }^{1}$ Danim, Sudarwan, dan Suparno, Manajemen dan Kepemimpinan Transformasional Kekepala Sekolahan: Visi dan Strategi Sukses Era Teknologi, Situasi Krisis, dan Internasional Pendidikan (Jakarta: Rineka Cipta, Tahun 2009), 178.

${ }^{2}$ Samani, Muchlas, Hariyanto, Pendidikan Karakter, (Bandung: PT Remaja Rosdakarya, Tahun 2011), 72.

${ }^{3}$ Musfah, J., Peningkatan Kompotensi Guru: Melalui Pelatihandan Sumber Belajar Teoridan Praktik (Jakarta: Kencana, Tahun 2011), 22\&16. 
Dalam kenyataan praktik sehari-hari di lingkungan sekolah masih banyak dijumpai adanya gejala-gejala dan perilaku peserta didik yang menunjukkan adanya kemerosotan akhlak, serta muncul tindak pelanggaran yang menjurus kepada negativisme pada kalangan pelajar. Kemerosotan akhlak yang berupa kenakalan remaja pada siswa biasanya terjadi pada tingkat SLTP dan SLTA. Pada usia tersebut, siswa mempunyai kecenderungan yang besar untuk mencoba sesuatu atau rasa ingin tahu, kebutuhan aktualisasi diri dan juga yang paling terberat seorang siswa adalah menjaga dirinya dalam pergaulan.

Berkaitan dengan kemerosotan moral siswa tersebut, sekolah sering dituntut untuk bertanggung jawab dengan keadaan itu. Sekolah sebagai sebuah lembaga pendidikan diharapkan tidak hanya sebagai tempat untuk memperoleh ilmu pengetahuan saja, tetapi juga diharapkan dapat memberi bekal yang cukup dalam membentuk kepribadian siswa yang tangguh dalam menghadapi era globalisasi. Demikian juga ajaran-ajaran moral dan tata nilai yang berlaku di masyarakat juga menjadi prioritas yang tidak dapat diabaikan sekolah untuk ditanamkan kepada siswa. Hal ini tercantum dalam undang-undang No.20 Tahun 2003 Tentang sistem pendidikan Nasional dinyatakan: Pendidikan adalah usaha sadar dan terencana untuk mewujudkan suasana belajar dan proses pembelajaran agar peserta didik secara aktif mengembangkan potensi dirinya untuk memiliki kekuatan spiritual, keagamaan, pengendalian diri, kepribadian, kecerdasan, akhlak mulia, serta ketrampilan yang diperlukan dirinya, masyarakat, bangsa, dan negara. ${ }^{4}$

Perilaku-perilaku yang menunjukkan kemerosotan akhlak pelajar di atas, diperlukan sebuah usaha yang sungguhsungguh dari pihak sekolah untuk mengantisipasi berbagai bentuk kenakalan siswa di sekolah. Salah satu cara yang dapat ditempuh adalah membangun akhlak siswa agar berbudi pekerti luhur, bertanggung jawab, berkepribadian kuat, dan jujur, serta membentuk karakter yang kuat dalam kehidupannya terutama moral yang berbentuk akhlakul karimah. Hal tersebut dapat dilakukan melalui pendidikan budi pekerti yang diintegrasikan pada setiap mata pelajaran maupun kegiatan ekstrakurikuler. Dan perlu ada upaya dan

\footnotetext{
${ }^{4}$ Syafri, Ulil Amri, Pendidikan Karakter Berbasis Al-Qur'an (Jakarta: PT. Raja Grafindo, Tahun 2012), 10.
} 
langkah-langkah strategis dalam pembentukan akhlak peserta didik. ${ }^{5}$ Upaya membentuk akhlak yang baik pada diri siswa, diperlukan pengaturan yang sistematis, seperti halnya manajemen pengajaran atau proses pembelajaran. Melalui proses pembelajaran, sekolah perlu memperhatikan pengembangan dan memperbaiki mental pada peserta didik. ${ }^{6}$ Dengan demikianlain, diperlukan sebuah manajemen khusus yang dikembangkan pihak sekolah untuk meningkatkan kualitas akhlak siswa. Berbagai upaya dalam penanganan kualitas akhlak siswa merupakan suatu tugas yang berat dan penuh tantangan. Untuk itu, diperlukan langkah terpadu dari berbagai pihak, baik sekolah, guru, siswa, organisasi kesiswaan, maupun peran serta orang tua siswa.

Sekolah secara tegas perlu mempunyai perencanaan sistem manajemen akhlak yang diberlakukan sebagai pedoman baku. Dalam sistem perencanaan manajemen akhlak tersebut, terdapat strategi yang dapat ditempuh sekolah untuk menanamkan nilainilai moral dan sekaligus sanksi yang diberlakukan bagi siswa yang melanggar aturan. Cara implementasi pendidikan akhlak yaitu mengintegrasikan pendidikan akhlak kedalam semua bidang studi. ${ }^{7}$ Selain itu, juga melalui kegiatan ekstrakurikuler, seperti pramuka, organisasi keagamaan di sekolah, peringatan hari keagamaan, dan kegiatan-kegiatan lain yang positif. Selain ketiga cara di atas, keteladanan kepala sekolah, guru, dan staf sekolah juga penting diperhatikan yang pada umumnya dijadikan acuan siswa dalam bertingkah-laku di sekolah.

Proses pendidikan ini merupakan salah satu indikator predikat sekolah yang unggulan. Sekolah unggulan adalah sekolah yang dikembangkan untuk mencapai keunggulan dalam keluaran (output) dan masukan (input) yang unggul disertai dengan proses pendidikan yang memadai. ${ }^{8}$ Sekolah ini sudah mempunyai sistem perencanaan

${ }^{5}$ Fitri, Agus Zaenul, Reinventing Human Character, Pendidikan Karakter Berbasis Nilai dan Etika Sekolah, (Yogyakarta: Ar-Ruzz, Tahun 2012). 69-70.

${ }^{6}$ Daryanto, Kepala Sekolah Sebagai Pemimpin Pembelajaran (Yogyakarta: Gava Media, Tahun 2011), 182.

${ }^{7}$ Ibid, 69-70.

${ }^{8}$ Abu Bakar, Usman, Paradigmadan Epistemology Pendidikan Islam, Panduan Penyelenggaraan Pendidikan Bagi Guru, Kepala Sekolah, dan Penyelenggara Pendidikan (Yogyakarta: UAB Media, Tahun 2013), 123. 
manajemen pendidikan akhlak yang diberlakukan kepada siswa, cara menanamkan nilai-nilai moral, dan sangsi yang diberikan bagi yang melanggar.

Dalam perencanaan, pengorganisasian, pelaksanaan dan pengawasan tersebut, terdapat juga evaluasi untuk menilai keberhasilan penanaman nilai-nilai moral yang dilakukan setiap tahun. Evaluasi ini penting dilakukan untuk melihat keberhasilan manajemen akhlak dan kelemahan sistem yang diberlakukan. Dari evaluasi, juga dapat diperoleh faktor-faktor penyebab dekadensi moral pada siswa. Temuan ini selanjutnya ditindak lanjuti agar diperoleh solusi, sehingga kenakalan serupa tidak terulang kembali pada siswa yang lain. Dalam pelaksanaan program tersebut, juga ditemui beberapa kendala yang menghambat dalam penanaman moral pada siswa.

Berdasarkan uraian di atas, penelitian ini bermaksud mengetahui bagaimana program implementasi pendidikan akhlak pada siswa dalam konteks manajemen pendidikan akhlak yang diberlakukan oleh Madrasah Aliyah Negeri (MAN) 1 Lombok Timur sebagai upaya preventif/represif dalam mengatasi bentuk-bentuk kenakalan siswa/remaja yang biasa terjadi di sekolah dan juga termasuk diluar sekolah karena yang paling penting juga dalam menanggulangi proses kenakalannya.

Kesalahan-kesalahan dan pelanggaranpelanggaran yang terjadi meskipun tergolong sepele, menunjukkan bahwa nilai-nilai akhlak terutama para siswa masih perlu ditingkatkan oleh pihak sekolah. Kepala sekolah sebagai orang yang paling bertanggung jawab di sekolah, maupun guru dan tenaga kependidikan pada sekolah tersebut perlu diteliti tentang sejauh mana mengaktualisasikan dirinya dan staf dilingkungan kerjanya dalam mengembangkan manajemen pendidikan akhlak di sekolah.

Fenomena permasalahan tentang menurunnya akhlak tersebut di atas, maka perlu dikaji melalui research atau penelitian tersendiri. Adapun kajian penelitian ini terfokus pada implementasi manajemen yang diterapkan dalam merealisasikan pendidikan akhlak di sekolah. Pentingnya kajian ini adalah dalam kerangka menuju kemajuan sekolah yang berkualitas dan unggul dengan berbasis nilai-nilai akhlak yang mulia, baik di lingkungan keluarga, sekolah dan masyarakat secara keseluruhan.

Berdasarkan uraian di atas, penelitian ini mengungkapkan keunikan di Madrasah Aliyah Negeri (MAN) 1 Lombok Timur sebagai sekolah umum, pada umumnya sekolah umum kurang berhasil dalam manajemen pendidikan akhlak, di 
samping itu, Madrasah Aliyah Negeri (MAN) 1 Lombok Timur yang mempunyai alokasi waktu pelajaran Implementasi Manajemen Pendidikan Akhlak yang dilaksanakn sebelum masuk seperti: mengaji dan ceramah/pidato sebelum masuk kelas, dan salah satu sekolah yang melakukan imtaq setiap hari kecuali hari senen karena apel tetapi setelah pelaksanaan apel ada kultum/tausyiah yang diberikan oleh guru sebelum masuk kelas, namun kenyataannya pendidikan akhlak yang diterapkan di sekolah tersebut berhasil.

\section{METODE PENELITIAN}

Jenis penelitian ini adalah penelitian kualitatif karena subjek yang diteliti adalah orang dengan segala aktivitasnya dan alam sekitarnya, penelitian kualitatif (qualitative research) adalah suatu penelitian yang ditujukan untuk mendeskripsikan dan menganalisis fenomena, peristiwa, aktivitas sosial, sikap, kepercayaan, persepsi, pemikiran orang secara individual maupun kelompok. ${ }^{9}$

Tujuan penelitian ini adalah untuk mendapatkan informasi mengetahui tentang Implementasi manajemen pendidikan akhlak, hambatan dan solusi dalam implementasi manajemen pendidikan akhlak, tujuan dan hasil dalam implementasi manajemen pendidikan akhlak di Madrasah Aliyah Negeri (MAN) 1 Lombok Timur.

Penelitian ini mengambil subjek di Madrasah Aliyah Negeri (MAN) 1 Lombok Timur Untuk sumber informasi dari MAN tersebut meliputi Subyek penelitian yakni: Kepala sekolah, wakaur kepala sekolah, guru, siswa dan komite sekolah. Dalam penelitian ini, sumber data menggunakan sampel purposive (purposive sample) yang memfokuskan pada informan-informan terpilih yang kaya dengan kasus untuk studi yang bersifat mendalam. Metode pengumpulan data penelitian ini dengan wawancara, observasi dan dokumentasi. Pemeriksahan keabsahan data ini dengan tringulasi. Sedangkan teknik analisis data penelitian ini adalah reduksi data, penyajian data dan penarikan kesimpulan atau verifikasi.

9 Sukmadinata, Nana Syaodih, Pendidikan Penelitian (Bandung: Remaja Rosdakarya, Tahun 2009), 69. 


\section{HASIL PENELITIAN}

Adapun hasil dari penelitian ini dalam implementasi manajemen pendidikan akhlak dilakukan pihak madrasah melalui tahap perencanaan, pelaksanaan, pengornisasian, pengawasan/evaluasi, hambatan/solusi, dan tujuan/hasil terhadap perubahan dan perbaikan program-program di madrasah.

Perencanaan manajemen pendidikan akhlak di madrasah dilakukan dengan membuat rencana silabus dan RPP yang bermuatan karakter/budi pekerti siswa yang berlandaskan nilai-nilai islam, merencanakan program pendidikan akhlak melalui kegiatan ekstrakulikuler dengan cara guru membuat rencana proposal kegiatan dan merencanakan program pendidikan akhlak siswa melalui kegiatan pembiasaan seperti: penerapan nilainilai islam dalam bentuk perilaku sehari-hari seperti shalat, tadarus, do'a, salam, jabat tangan, dan lain.

Pengkordinasian pendidikan akhlak siswa di MAN Selong, mengadakan kordinasi dengan guru, karyawan, dan rohis dalam melaksanakan pendidikan akhlak siswa (kerjasama internal). Di samping itu madrasah juga melibatkan pihak lain dalam pendidikan akhlak siswa, contohnya komite madrasah, orang tua siswa, dan instansi terkait yaitu dengan kapolsek kecamatan Selong, Dinas kesehatan puskesmas kecamatan Selong, kepala lurahSelong, tokoh masyarakat Selong, tokoh agama pondok pesantren, pengawas madrasah dari Dinas/Kemenag kabupaten Selong, pakar pendidikan (dosen).dan Universitas yang ada di NTB (eksternal).

Implementasi manajemen pendidikan akhlak di madrasah, kegiatan pembelajaran dimulai, selama 15-25 menit diawali dengan sholat Dhuhah, membaca do'a dan membaca beberapa ayat atau surat yasin setelah itu diberikan tausyiah oleh guru dan diberikan waktu untuk siswa berpidato dalam mengasah kemampuannya untuk berbicara didepan umum. Sedangkan Pada akhir pelajaran secara bersamasama membaca do'a dengan dibimbing oleh guru yang mengampu pelajaran terakhir.

Pengawasan/evaluasi manajemen pendidikan akhlak di madrasah melalui supervisi berguna untuk memberikan penilaian sementara terhadap bawahan. Apakah sudah sesuai dengan yang telah direncanakan atau belum, disamping hasil pengawasan juga dapat digunakan untuk mengadakan perbaikan dan penyempurnaan. Seperti contoh mengawasi kegiatan imtaq, shalat dzhuhur, shalat dhuha, imtaq jum'at, apel dan mengikutinya. 
Faktor penghambat dan solusi manajemen pendidikan akhlak di MAN 1 Lombok Timur, siswa terlambat mengikuti kegiatan sholat Dhuha', Imtaq pagi, apel setiap hari senen, Dzhuhur berjamaah dan terlambat masuk kelas, masih terdapat siswa yang menunda waktu atau bermalas-malasan dalam menjalankan tugas dan kewajibannya seperti memperlambat datang, bercakapcakap dan bermain maupun bersenda gurau.

Solusinya dengan mengoptimalkan peran aktif guru maupun karyawan dalam kegiatan-kegiatan keagamaan maupun kegiatan yang diadakan oleh madrasah dan untuk siswa selalu diberi pembinaan dan pembimbingan yang berkesinambungan.

Tujuan dalam melaksanakan pendidikan akhlak dimadrasah adalah yang pertama tidak lain untuk pembentukan karakter anak, membiasakan peserta didik dalam bermoral baik, keras kemauan, sopan dalam berbicara dan perbuatan, mulia dalam bertingkah laku, bijaksana, sempurna, sopan dan beradab, ikhlas, jujur dan suci. Jadi fungsi pendidikan akhlak menekan pada sikap, tabi'at, dan perilaku yang menggambarkan nilai-nilai kebaikan yang harus dimiliki dan dijadikan kebiasaan peserta didik dalam sehari-hari.

Hasil dalam implementasi manajemen pendidikan akhlak dimadrasah berjalan dengan baik walaupun masih memerlukan pengawasan lagi, hasil dalam menjalankan pelaksanaan ini mampu memberikan dorongan, dan mampu menjadi madrasah yang unggul dalam prestasi akademik maupun non akademik.

Keberhasilan pendidikan akhlak MAN 1 Lombok Timur tidak terlepas dari kreatifitas kepala madrasah dalam mengelola pendidikan akhlak di madrasah tersebut. Adapun penyebab keberhasilan manajemen pendidikan akhlak di madrasah adalah: Kepala madrasah mampu menciptakan suasana yang kondusif di lingkungan madrasah, mampu menumbuhkan budaya islam di madrasah melalui kegiatan pembiasaan imtaq dan budaya islami, membuat peraturan madrasah tentang disiplin waktu, disiplin kerja, komitmen. Berusaha mengelola segenap sumber daya pendidikan akhlak, menggalang kerjasama yang baik dan harmonis para guru, karyawan, kebersamaan dan kekompakan, mengadakan kordinasi dengan pihak terkait dalam bentuk partisipasi dari berbagai pihak, memberikan motivasi yang dapat mempengaruhi pola pikir/mindseat para pembina, guru dan karyawan yang didasari oleh nilai-nilai islami. 


\section{PEMBAHASAN}

Berdasarkan data penelitian, pelaksanaan pendidikan akhlak yang diterapkan di MAN 1 Lombok Timur, peneliti selanjutnya melakukan pembahasan terhadap peran penting kepala madrasah dan guru maupun karyawan dalam implementasi pendidikan akhlak di lingkungan kerjanya. Adapun hasil dari pembahasan tersebut adalah melalui keteladanan, pendidikan, pengajaran serta pembinaan kepada semua warga madrasah. Peran kepala madrasah dalam implementasi pendidikan akhlak di MAN menjadi sumber inspirasi terhadap perubahan-perubahan dalam kerangka pengembangan pendidikan akhlak di madrasah.

Menurut analisa peneliti jika dikategorikan maka sudah sesuai dengan teori manajemen pendidikan karena dalam proses untuk mencapai tujuan pendidikan akhlak siswa, kepala madrasah telah melaksanakan fungsi-fungsi manajemen yaitu: planning, organizing, commanding, coordinating dan controlling, yang dikemukakan oleh Fayol yang dikutif. ${ }^{10}$ Adapun tahapan secara rinci adalah sebagai berikut:

Pertama: Implementasi manajemen pendidikan akhlak di MAN 1 Lombok Timur.

Perencanaan manajemen pendidikan akhlak di madrasah yakni merencanakan program pendidikan akhlak melalui kegiatan intrakurikuler dengan membuat rencana silabus dan Rencana Program Pembelajaran (RPP) yang bermuatan karakter/budi pekerti siswa yang berlandaskan nilai-nilai islam yang harus disusun oleh semua guru mata pelajaran. Program pendidikan akhlak melalui kegiatan ekstrakulikuler ini yang harus disusun oleh guru pembimbing ekstrakulikuler dengan cara guru membuat rencana proposal kegiatan ekstrakulikuler yang mencakup materi, tujuan, dasar pelaksanaan, objek, waktu pelaksanaan, internalisasi pendidikan akhlak dalam kegiatan tersebut. Dan merencanakan program pendidikan akhlak siswa melalui kegiatan pembiasaan, Perencanaan pembiasaan ini adalah latihan-latihan penerapan nilai-nilai islam dalam bentuk perilaku sehari-hari.

Perencanaan tersebut di atas sudah baik, internalisasi nilai-nilai islam yang diterapkan pada kegiatan pendidikan di MAN 1 Lombok Timur sudah sesuai dengan tujuan pendidikan nasional yang termuat dalam Undang-Undang nomor 20 Tahun

${ }^{10}$ Mulyono, Manajemen Administrasi dan Organisasi Pendidikan, (Yogyakarta: Arruz Media Group, Tahun, 2008), 23. 
2003 pasal 3 tentang Sistem Pendidikan Nasional, tujuan pendidikan nasional yaitu salah satunya untuk berkembangnya potensi peserta didik agar menjadi manusia yang beriman dan bertaqwa kepada Tuhan Yang Maha Esa, berakhak mulia.Secara praktis pendidikan akhlak siswa di MAN 1 Lombok Timur sudah berhasil, terbukti adanya budaya islam di madrasah, walaupun ada beberapa yang belum maksimal dilaksanakan.

Pengorganisasian dan kordinasi pendidikan akhlak madrasah mempunyai struktur kepengurusan madrasah dalam hal ini kepala madrasah mengadakan kordinasi dengan guru, karyawan, dan rohis dalam melaksanakan pendidikan akhlak siswa (kerjasama internal). Di samping itu madrasah juga melibatkan pihak lain dalam pendidikan akhlak siswa, contohnya komite madrasah, orang tua siswa, dan instansi terkait yaitu dengan kapolsek kecamatan Selong, Dinas kesehatan puskesmas kecamatan Selong, kepala lurah Selong, tokoh masyarakat Selong, tokoh agama pondok pesantren, pengawas sekolah dari Dinas/Kemenag kabupaten Selong, pakar pendidikan (dosen), dan Universitas yang ada di NTB (kerja sama eksternal). Pengorganisasian juga terwujud pada distribusi tugas guru-guru dalam membimbing kegiatan pendidikan akhlak siswa sesuai dengan keahliannya.

Proses pengorganisasian adalah merupakan kegiatan menempatkan seseorang dalam struktur organisasi sehingga memiliki tanggung jawab tugas dan kegiatan yang berkaitan dengan fungsi organisasi dalam mencapai tujuan yang disepakati bersama melalui perencanaan, seperti membagikan pekerjaan yang harus dikerjakan, membagi tugas kepada karyawan untuk melaksanakannya, mengalokasikan sumber daya yang memberikan bantuan, kemudian mengkoordinir pekerjaan untuk mencapai hasil dan tujuan yang diinginkan. ${ }^{11}$

Implementasi pendidikan akhlak di madrasah ini melalui intra kulikuler, ekstrakurikuler dan pembiasaan. Pada kegiatan intrakulikuler maupun ekstrakulikuler melalui mata pelajaran yang dilaksanakan di MAN Selong membuktikan bahwa guru berperan aktif dalam proses pembelajaran di kelas maupun di luar kelas. Urgensi peran guru ini karena mereka yang berhadapan langsung dengan para pelajar.

\footnotetext{
${ }^{11}$ Syaifarudin, Manajemen Sumber Daya Manusia, Strategi Keunggulan Kompetitif, (Yogyakarta: Badan Penerbitfakultas Ekonomi, Yogyakarta, Tahun 2005), 73.
} 
Intrakulikuler dilakukan dengan cara penanaman karakter/budi pekerti yang berlandaskan nilai-nilai ajaran islam dalam proses belajar mengajar oleh guru terhadap siswa diintegrasikan dengan materi yang disampaikan pada semua mata pelajaran, juga dalam interaksi guru dan siswa di kelas. Kegiatan kebiasaan imtaq bersama di saat sebelum pelajaran di mulai ini keterlibatan guru dalam pembiasaan imtaq ini diharapkan menjadi inspirasi bagi para siswa untuk senang mengaji, belajar, membaca, memahami, menghayati dan mengamalkan serta mengajarkan ilmu AlQuran, Kitabkitab di lingkungan keluarga maupun dalam hidup dan kehidupannya.

Dalam pelaksanaan manajemen pendidikan di MAN 1 Lombok Timur sudah sesuai dengan ruang lingkup materi akhlak dan berjalan lancar atau bisa dikatan sudah berhasil menjalankannya, ruang lingkup materi akhlak ini sesuai yang ada dan juga sesuai dengan sumber ajaran islam yaitu Al-quranul Karim dan ajaran Rasulullah SAW yang meliputi akhlak kepada Tuhan (beribadah shalat dll), akhlak kepada diri sendiri (membersihkan diri dari perbuatan tercela dan melakukan perbuatan terpuji), akhlak kepada sesama manusia (hubungan dengan sesama teman, guru, orang tua, dengan baik), dan akhlak kepada makhluk lain (menjaga alam sekitar), teori tokohtokoh islam.

Pengawasan/evaluasi pendidikan akhlak dimadrasah. Supervisi biasa dilakukan berkala setiap 6 bulan sekali di dalam kelas proses KBM, pengawasan (pemantauan) juga dengan cara berkomunikasi antara guru dan orang tua siswa melalui ponsel, guru bisa menghubungi orang tua siswa atau sebaliknya, pengawasan (pemantauan) pelaksanaan pendidikan akhlak siswa juga dilakukan di lingkungan masyarakat, yaitu melalui pengawasan tokoh masyarakat, tokoh agama, kepala lurah yang membantu langsung dan bekerja sama dengan pihak keamanan.

Pengawasan spiritual itu lebih penting dan mutlak diperlukan sebagai manusia beriman kepada Allah SWT, bahwa pengawasan dalam pendidikan islam mempunyai karateristik yang di katakan oleh ilmuan. ${ }^{12}$ Pengawasan bersifat material dan spiritual. ${ }^{13}$

\footnotetext{
${ }^{12}$ Ramayulis, Ilmu Pendidikan Islam, (Jakarta: Kalam Mulia, Tahun, 2008), 274.

${ }^{13}$ Saefullah, Manajemen Pendidikan Islam (Penerbit: Pustaka Setia, Tahun, 2012), 38.
} 
Kedua: Hambatan dan solusi dalam implementasi manajemen pendidikan akhlak di akhlak di MAN 1 Lombok Timur

Faktor dari individu siswa yang kurang tertib, kurang disiplin diri, kurang tanggungjawab atas tugas yang diberikan dan kurang mengerti yang disampaikan guru. Ada beberapa siswa yang terlambat mengikuti kegiatan sholat Dhuha', Imtaq pagi, apel setiap hari senen, Dzhuhur berjamaah dan terlambat masuk kelas, siswa yang menunda waktu atau bermalas-malasan dalam menjalankan tugas dan kewajibannya seperti memperlambat datang, bercakapcakap dan bermain maupun bersenda gurau. Faktor dari lingkungan sekolah terutama para guru dan tenaga kependidikan lainnya, ada beberapa guru dan karyawan yang belum berpartisipasi aktif/ terjun langsung dalam kegiatan keagamaan. Faktor dari lingkungan keluarga dan masyarakatnya, kurang memperhatikan/ mengontrol para siswa dan kurang paham yang apa yang dikatakan/jelaskan oleh pihak madrasah.

Faktor tersebut akan menjadi penghambat dalam penanaman pendidikan akhlak, maka perlu mendapatkan perhatian yang serius baik itu dari dalam madrasah maupun luar madrasah. Hambatan tersebut berupa sikap mental rendah yang ditandai kurang disiplin, sering datang terlambat, kurang bertanggung jawab atas tugasnya. Sedangkan hambatan eksternalnya adalah berasal dari lingkungan keluarga, masyarakat (teman masyarakat). ${ }^{14}$

Solusi yang dilakukan dalam menghadapi tantangan dalam pendidikan akhlak di MAN 1 Kabupaten Lombok Timur adalah Pertama, jika itu dari dalam (guru, karyawan dan siswa) diadakan pembinaan secara berkesinambungan yang ada kaitannya dengan masalah tersebut. Jika itu menyangkut siswa dengan memberikan layanan konseling kepada peserta didik, melaksanakan kegiatan ekstra dan kokurikuler untuk para peserta didik, melakukan pembinaan prestasi unggulan agar akhlakul karimah mampu diwujudkan. Jika itu dari luar madrasah melibatkan warga dan masyarakat pendukung madrasah dalam mengelola pendidikan baik secara akademik dan non akademik.

${ }^{14}$ Mulyasa, E., Menjadi Kepala Sekolah Profesional (Bandung: Remaja Rosdakarya, Tahun 2013),73-75. 
Ketiga: Tujuan dan hasil implementasi manajemen pendidikan akhlak di akhlak di MAN 1 Lombok Timur.

Tujuan implementasi manajemen pendidikan akhlak di madrasah adalah yang pertama tidak lain untuk pembentukan karakter anak, membiasakan peserta didik dalam bermoral baik, keras kemauan, sopan dalam berbicara dan perbuatan, mulia dalam bertingkah laku, bijaksana, sempurna, sopan dan beradab, ikhlas, jujur dan suci.

Keberhasilan pendidikan akhlak MAN 1 Lombok Timur tidak terlepas dari kreatifitas kepala madrasah dalam mengelola pendidikan akhlak di madrasah tersebut. Adapun penyebab keberhasilan manajemen pendidikan akhlak di madrasah adalah: Kepala madrasah mampu menciptakan suasana yang kondusif di lingkungan madrasah, mampu menumbuhkan budaya islam di madrasah melalui kegiatan pembiasaan imtaq dan budaya islami, membuat peraturan madrasah tentang disiplin waktu, disiplin kerja, komitmen. Berusaha mengelola segenap sumber daya pendidikan akhlak, menggalang kerjasama yang baik dan harmonis para guru, karyawan, kebersamaan dan kekompakan, mengadakan kordinasi dengan pihak terkait dalam bentuk partisipasi dari berbagai pihak, memberikan motivasi yang dapat mempengaruhi pola pikir/mindseat para pembina, guru dan karyawan yang didasari oleh nilai-nilai islami.

\section{SIMPULAN}

Berdasarkan hasil penelitian menunjukkan bahwa Implementasi manajemen pendidikan akh lak yang diberlakukan di MAN Selong Kabupaten Lombok Timur meliputi perencanaan, pelaksanaan, pengornisasian, dan pengawasan/ evaluasi. Pengintegrasian pendidikan akhlak ke dalam semua bidang studi. Meskipun peran kepala madrasah dalam pendidikan akhlak sudah baik, namun peran guru dalam pendidikan akhlak siswa belum optimal. Kepedulian komite madrasah (orang tua siswa) terhadap pendidikan akhlak masih rendah.

Adapun menghambat implementasi manajemen pendidikan akhlak di MAN

Selong Kabupaten Lombok Timur antara lain disebabkan 2 faktor: meliputi dua faktor yakni: faktor internal dan faktor eksternal. Faktor hambatan internal berasal dari dari lingkungan sekolah berupa kurang disiplinnya guru dalam mengajar, kurang 
komunikatif, dan sertafasilitas ibadah yang belum memadai, input tanpa penyeleleksian, kemampuan siswa rata-rata kurang baik, dan orang tua dengan latar belakang pendidikan yang kurang mendukung dalam mendidik anak. Sedangkan faktor eksternal berasal dari luar lingkungan madrasah seperti pengaruh keluarga yang kurang peduli dan kurang perhatian, lingkungan atau teman masyarakat. Serta berupa dampak negatif globalisasi berpengaruh terhadap akhlak peserta didik.

Solusi mengatasi implementasi manajemen pendidikan akhlak di MAN 1 Lombok Timur berupa upaya yang dilakukan oleh MAN 1 Lombok Timur dengan jalan meningkatkan dan memperbanyak kegiatan ekstrakurikuler yang lebih efektif, meningkatkan koordinasi dengan masyarakat dan orang tua, serta memonitoring aktivitas siswa.

Penyebab keberhasilan manajemen pendidikan akhlak di madrasah adalah: Kepala madrasah mampu menciptakan suasana yang kondusif di lingkungan madrasah, mampu menumbuhkan budaya islam di madrasah melalui kegiatan pembiasaan imtaq dan budaya islami, membuat peraturan madrasah tentang disiplin waktu, disiplin kerja, komitmen. Berusaha mengelola segenap sumber daya pendidikan akhlak, menggalang kerjasama yang baik dan harmonis para guru, karyawan, kebersamaan dan kekompakan, mengadakan kordinasi dengan pihak terkait dalam bentuk partisipasi dari berbagai pihak, memberikan motivasi yang dapat mempengaruhi pola pikir/mindseat para pembina, guru dan karyawan yang didasari oleh nilai-nilai islami.

\section{SARAN}

Bagi Kepala sekolah, perlu memperjuangkan lembaganya sebagai lembaga yang unggul dan mampu berkompetisi dengan lembaga sekolah lainnya dan mempunyai inovasi baru, kedisiplinan diri dan rasa tanggungjawab, meningkatkan kerjasama dengan berbagai pihak, dalam meningkatkan kinerja untuk mencapai tujuan dan yang lebih efektif dan efisien dengan jalan mengembangkan pendidikan akhlak di madrasah. Para guru atau karyawan, meningkatkan semangat, komitmen dalam usaha mengembangkan pendidikan akhlak di madrasah berupa mendisiplinkan diri dalam pelaksanaan tugas dan kewajibannya serta menjalin hubungan kekerabatan atau kolegial antar warga madrasah secara harmonis. 
Upaya untuk meningkatkan hasil belajar siswa dan pelaksanaan manajemen pendidikan akhlak, hendaknya sekolah meningkatkan kerjasamayang baik dengan lembaga-lembaga terkait, orang tua dan masyarakat.

\section{REFERENCES}

Abu Bakar, Usman, (2013). Paradigmadan Epistemology Pendidikan Islam, Panduan Penyelenggaraan Pendidikan Bagi Guru, Kepala Sekolah, dan Penyelenggara Pendidikan, Yogyakarta: UAB Media.

Danim, Sudarwan, dan Suparno. (2009). Manajemen dan Kepemimpinan Transformasional Kekepala Sekolahan: Visi dan Strategi Sukses Era Teknologi, Situasi Krisis, dan Internasional Pendidikan, Jakarta: Rineka Cipta.

Daryanto, (2011). Kepala Sekolah Sebagai Pemimpin Pembelajaran, Yogyakarta: Gava Media.

Fitri, Agus Zaenul, (2012). Reinventing Human Character, Pendidikan Karakter Berbasis

Nilai dan Etika Sekolah. Yogyakarta: Ar-Ruzz.

Jasmani, Asfdan Syaiful Mustofa (2013). Supervisi Pendidikan: Terobosan Baru Dalam Kinerja Peningkatan Kerja Pengawas Sekolah Dan Guru, Yogyakarta: ArRuzz Media.

Mulyasa, E., (2013). Menjadi Kepala Sekolah Profesional, Bandung: Remaja Rosdakarya.

Musfah, J. (2011). Peningkatan Kompotensi Guru: Melalui Pelatibandan Sumber Belajar Teoridan Praktik, Jakarta: Kencana.

Ramayulis, (2008). Ilmu Pendidikan Islam, Jakarta: Kalam Mulia.

Samani, Muchlas, Hariyanto, (2011) Pendidikan Karakter, Bandung: PT. Remaja Rosdakarya.

Saefullah. (2012). Manajemen Pendidikan Islam, Penerbit: Pustaka Setia.

Sukmadinata, Nana Syaodih (2009). Pendidikan Penelitian, Bandung: PT. Remaja Rosdakarya.

Syafri, UlilAmri. (2012). Pendidikan Karakter Berbasis Al-Qur'an, Jakarta: PT. Raja Grafindo.

Syaifarudin, (2005). Manajemen Sumber Daya Manusia, Strategi Keunggulan Kompetitif, Yogyakarta: Badan Penerbitfakultas Ekonomi, Yogyakarta. 